\title{
MedChemComm
}

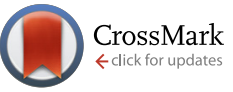

Cite this: Med. Chem. Commun., 2017, 8, 202

Received 15th September 2016, Accepted 11th November 2016

DOI: $10.1039 / c 6 m d 00523 c$

www.rsc.org/medchemcomm

\section{Determination and reduction of translocator protein (TSPO) ligand rs6971 discrimination $\dagger$}

\author{
Renee Sokias, $t^{\mathrm{a}}$ Eryn L. Werry, $t^{\text {bc }}$ Sook W. Chua,,$^{\mathrm{d}}$ Tristan A. Reekie, ${ }^{a}$ \\ Lenka Munoz, ${ }^{e}$ Erick C. N. Wong, ${ }^{c}{ }^{\text {Lars M. M. Itner }}{ }^{d}$ and Michael Kassiou ${ }^{\star a}$
}

\begin{abstract}
The $18 \mathrm{kDa}$ translocator protein (TSPO) is a target for development of diagnostic imaging agents for glioblastoma and neuroinflammation. Clinical translation of TSPO imaging agents has been hindered by the presence of a polymorphism, rs6971, which causes a non-conservative substitution of alanine for threonine at amino acid residue 147 (TSPO A147T). Disclosed brain-permeant second-generation TSPO ligands bind TSPO A147T with reduced affinity compared to the wild type protein (TSPO WT). Efforts to develop a TSPO ligand that binds TSPO WT and TSPO A14TT with similarly high affinity have been hampered by a lack of knowledge about how ligand structure differentially influences interaction with the two forms of TSPO. To gain insight, we have established human embryonic kidney cell lines stably over-expressing human TSPO WT and TSPO A147T, and tested how modifications of a novel $\mathrm{N}$-alkylated carbazole scaffold influence affinity to both TSPO isoforms. Most of the new analogues developed in this study showed high affinity to TSPO WT and a 5-6-fold lower affinity to TSPO A147T. Addition of electron-withdrawing substituents yielded analogues with highest affinity for TSPO A14T without decreasing affinity for TSPO WT. This knowledge can be used to inform further development of non-discriminating TSPO ligands for use as diagnostic markers for glioblastoma and neuroinflammation irrespective of rs6971.
\end{abstract}

\section{Introduction}

The translocator protein (TSPO) is an $18 \mathrm{kDa}$ outer mitochondrial membrane protein. ${ }^{1}$ Endogenous ligands include protoporphyrin IX and cholesterol, ${ }^{1}$ and early in vitro work demonstrated a role for TSPO in heme synthesis, cholesterol translocation and steroidogenesis. ${ }^{2,3}$ More recent in vivo knockout studies, however, have failed to find robust changes in heme metabolism, mitochondrial cholesterol transport and serum pregnenolone levels. ${ }^{4,5}$ More concordant evidence links the TSPO to a role in proliferation and apoptosis, particularly in cancer cells. Upregulation of TSPO in C6 glioblastoma cells enhances cell proliferation while cell lines with decreased TSPO levels show lower proliferation. ${ }^{6}$ Intriguingly, numerous chemotherapeutic agents that induce glioblastoma apoptosis

\footnotetext{
${ }^{a}$ School of Chemistry, The University of Sydney, NSW 2006, Australia. E-mail: michael.kassiou@sydney.edu.au

${ }^{b}$ Faculty of Health Sciences, The University of Sydney, NSW 2006, Australia ${ }^{c}$ School of Medical Sciences (Pharmacology), Bosch Institute, The University of Sydney, NSW 2006, Australia

${ }^{d}$ Dementia Research Unit, School of Medical Sciences, University of New South Wales, NSW 2052, Australia

${ }^{e}$ School of Medical Sciences (Pathology) and Charles Perkins Centre, The

University of Sydney, NSW 2006, Australia

$\dagger$ The authors declare no competing interests.

\$ Joint first authors.
}

require intact TSPO to exert their effects, and direct ligation of the TSPO both in vitro and in vivo can induce apoptosis and anti-proliferative effects in cancer cells. ${ }^{6}$

Clinical interest in TSPO ligands stems partly from the observation that TSPO is expressed at low levels in the healthy brain, but appears at up to 15-times higher levels

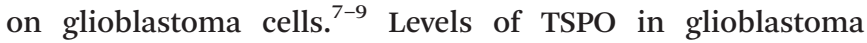
tumours correlate with severity and clinical outcome. ${ }^{7-9}$ Furthermore, TSPO is upregulated on activated glia during neuroinflammation. ${ }^{10-13}$ In addition to pre-clinical data, ${ }^{11,14-17}$ a number of small clinical trials have demonstrated the utility of TSPO imaging in brain tumours and neuroinflammatory disorders. For example, a 2-fold higher level of radioactivity was found in glioma tissue compared to non-malignant brain tissue in patients injected with a radiolabelled TSPO ligand ${ }^{18}$ and quantification of the radiolabelled TSPO ligand (123)I-CLINDE using SPECT proved useful for predicting glioblastoma progression. ${ }^{19}$ Increased TSPO ligand PET signal was found in the brains of patients with neuroinflammatory disorders such as HIV, presymptomatic Huntington's disease, temporal lobe epilepsy, mild cognitive impairment and Alzheimer's disease. ${ }^{17,20-22}$ Furthermore, injection of the immunogen lipopolysaccharide into healthy humans resulted in a $30-60 \%$ increase in brain signal of the TSPO ligand [(11)C]PBR28, concurrent with increased blood levels of inflammatory 
cytokines. $^{23}$ These suggest the TSPO shows good clinical promise as an imaging marker for glioblastoma and neuroinflammation.

The clinical translation of TSPO imaging agents has been hindered by variation in the affinity of TSPO ligands across human subjects. Almost every known brain-permeable secondgeneration TSPO ligand binds TSPO with high affinity in some healthy subjects (high affinity binders; HABs) but low affinity in other healthy subjects (low affinity binders; LABs). For example the affinities of DPA-713, XBD-173 and PBR-28 show a 4-, 13and 55-fold reduction, respectively, in brain tissue or lymphocytes from LABs compared to HABs. ${ }^{24,25}$ This reduction in affinity is attributed to the single nucleotide polymorphism, rs6971, present in $30 \%$ of the Caucasian population and at lower levels in African American, Han Chinese and Japanese subjects. ${ }^{26}$ The rs6971 polymorphism results in a non-conservative substitution of alanine for threonine at amino acid residue 147 (TSPO A147T) which falls in the fifth transmembrane domain, within a potential ligand binding site. ${ }^{27}$ The crystal structure of the bacterial homolog of TSPO A147T (34\% homology) suggests this mutation moves the second and fifth transmembrane domains closer together than in the wild type TSPO (TSPO WT). ${ }^{27}$ This has a clinical impact, as administration of radiolabelled versions of DPA-713 and PBR-28 to rs6971 homo- or heterozygotes produces a lower brain PET signal than in wild type homozygotes. ${ }^{25}$ This necessitates subjects to be genotyped for their rs6971 status and that neuroimaging results be interpreted in light of their genotype. ${ }^{26}$

A more ideal situation would involve development of a ligand that could bind with equally high affinity to both TSPO WT and A147T. While the affinity of the first-generation TSPO ligand PK 11195 is not affected by the presence of the polymorphism, ${ }^{25}$ PK 11195 has highly variable kinetics and poor in vivo bioavailability. ${ }^{28,29}$ Development of non-discriminating ligands based on high affinity brain-permeable second generation TSPO ligands has been hindered by a paucity of knowledge about how ligand structure influences discrimination between the TSPO WT and A147T. To this end, we have established human embryonic kidney (293T) cell lines over-expressing human TSPO WT and A147T to allow for high throughput assessment of TSPO ligand discrimination. Using these isogenic cell lines, we explored how modifications of a novel $N$-alkylated carbazole scaffold influence affinity at both TSPO forms, generating new insight into the different binding requirements of TSPO WT and A147T. The carbazole scaffold was chosen as a simple and commercially available analogue to known nitrogen-containing tricyclic TSPO ligands such as SSR-180,575, XBD-173 and DPA713. The carbazole building block could be readily $\mathrm{N}$-substituted with acetamides and functionalised through cross-coupling to explore the requirements for TSPO WT and A147T selectivity.

\section{Results and discussion}

\section{Synthesis of compounds}

The carbazole acetamide derivatives were synthesised according to the synthetic scheme shown in Fig. 1. Briefly, the synthetic route follows a three-step pathway. Regioselective bromination of the commercially available $9 H$-carbazole (1) with $\mathrm{N}$-bromosuccinimide provided the $9 \mathrm{H}$-carbazole 2. Subsequent NH-deprotonation of 1 or 2 with sodium hydride, followed by the addition of the alkylating agents gave the required carbazole acetamide derivatives, $\mathbf{3 a}-\mathbf{b}$ and 4a-4b. A palladium-catalysed Suzuki-Miyaura cross-coupling reaction with the required boronic acid derivative gave the corresponding freely rotating phenyl group 5a-5c.

\section{Validation of cell lines}

In order to study differential binding of compounds to TSPO WT and A147T, we established novel cell lines, each stably expressing one of the TSPO variants (Fig. 2). Cell lines were derived from clonally selected $293 \mathrm{~T}$ cells that have been transduced with lentiviruses, which either encode human TSPO WT or A147T for stable integration into their genome. Western blotting of protein extracts showed comparable expression levels of human TSPO WT and A147T in the respective cell lines, but interestingly, lower total levels of TSPO compared to endogenous TSPO in non-transfected controls (Fig. 2A). Furthermore, confocal microscopy demonstrated that both human TSPO WT and A147T localized virtually exclusively to mitochondria, without changes to mitochondrial patterns (Fig. 2B). Hence, we have established two new cell lines expressing human TSPO WT and A147T, suitable for pharmacological assessment of compounds.

As this is the first description of cell lines engineered to over-express the TSPO WT or A147T, we examined the affinity of TSPO ligands PK 11195, DPA-713 and XBD-173, which have been well characterised in human tissue from low and high affinity TSPO binders. In saturation radioligand binding experiments using cell membranes from 293T cells overexpressing TSPO WT and A147T, $K_{\mathrm{d}}$ values of $13.7 \pm 5.9 \mathrm{nM}$ and $13.4 \pm 2.2 \mathrm{nM}$, respectively, were determined for $\left[{ }^{3} \mathrm{H}\right]$-PK 11195. Equal affinity of PK 11195 towards TSPO WT and A147T was recapitulated in competition radioligand binding assays (Table 1), mirroring the lack of sensitivity of PK 11195 to the mutated TSPO in human brain tissue. ${ }^{30}$ Although the

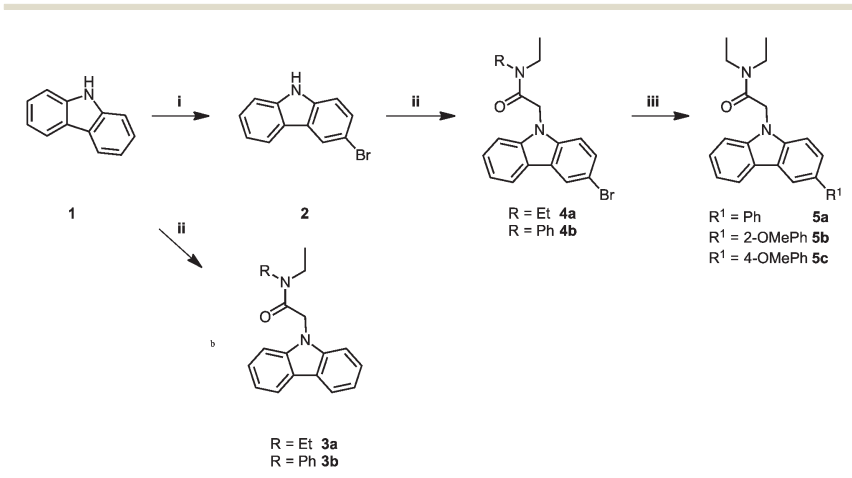

Fig. 1 Synthesis of carbazole acetamide derivatives. Conditions and reagents: (i) NBS, DMF, dark, $0{ }^{\circ} \mathrm{C}-\mathrm{RT}, 8 \mathrm{~h}$; (ii) corresponding alkylating agent, $\mathrm{NaH}, \mathrm{THF}, 0^{\circ} \mathrm{C}-\mathrm{RT}, 1 \mathrm{~h}$; (iii) boronic acid derivative, $\left[\mathrm{Pd}\left(\mathrm{PPh}_{3}\right)_{4}\right], \mathrm{Cs}_{2} \mathrm{CO}_{3}$, toluene, $95^{\circ} \mathrm{C}$, argon, $24 \mathrm{~h}$. 


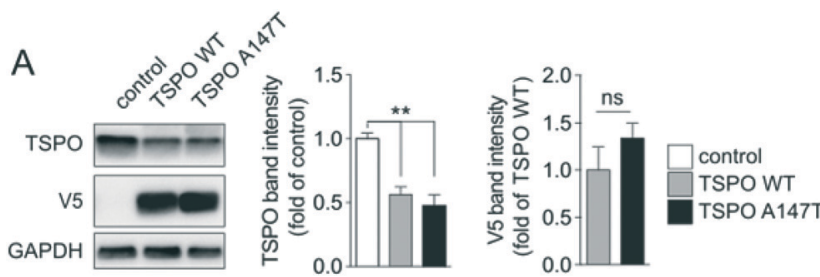

B hTSPO-v5
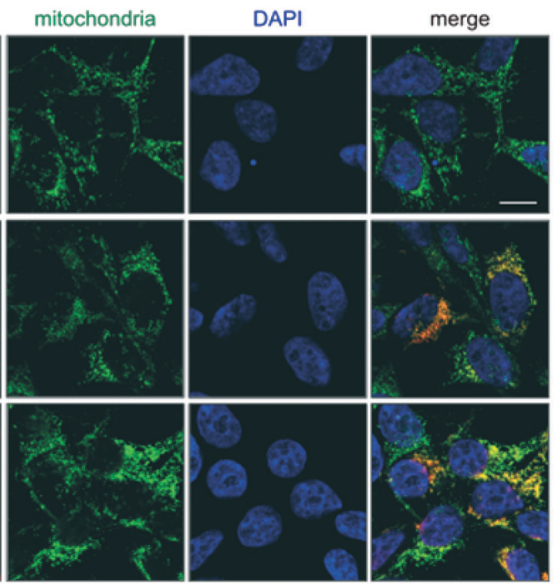

Fig. 2 TSPO WT or A147T-expressing cells. (A) Western blotting and quantification (3 independent blots) of stably expressing 293T cells and (B) confocal microscopy together with staining for V5-tagged TSPO WT or A147T and the mitochondrial marker porin. Merges confirm mitochondrial localization of expressed TSPO variants. Scale bar, $10 \mu \mathrm{m}$.

affinity of PK 11195 to human TSPO seen in this study is lower than that commonly reported at the rat TSPO (0.7-18 $\mathrm{nM}),{ }^{31}$ it aligns almost exactly with that reported in human brain tissue (28.5-30.6 nM), ${ }^{30}$ adding to reports of species differences in binding of other scaffolds to the TSPO. ${ }^{32,33}$

These novel cell lines also recapitulate the drop-off in affinity of DPA-713 and XBD-173 at human brain tissue from LABs versus HABs (Table 1). ${ }^{24,25}$ DPA-713 produced a 5-fold drop off in affinity at TSPO A147T compared to TSPO WT, which is similar to the 4.4-fold loss in affinity in human brain tissue from LAB's compared to HAB's. ${ }^{25}$ XBD-173 showed a 5-fold loss in affinity at TSPO A147T, and while this

Table 1 TSPO binding affinities $\left(K_{\mathrm{i}}\right)$ of carbazole derivatives using membranes from TSPO WT and A147T over-expressing 293T cells. Values represent the mean \pm SEM from at least three independent experiments performed in duplicate

\begin{tabular}{|c|c|c|c|}
\hline Compound & $\begin{array}{l}\text { TSPO WT } \\
K_{\mathrm{i}}(\mathrm{nM})\end{array}$ & $\begin{array}{l}\text { TSPO A147T } \\
K_{\mathrm{i}}(\mathrm{nM})\end{array}$ & $\begin{array}{l}\text { TSPO A147T } K_{\mathrm{i}} / \mathrm{TSPO} \\
\text { WT } K_{\mathrm{i}}\end{array}$ \\
\hline PK 11195 & $29.2 \pm 7.3$ & $36.0 \pm 6.8$ & 1.2 \\
\hline DPA-713 & $19.5 \pm 3.5$ & $98.8 \pm 2.3$ & 5.1 \\
\hline XBD-173 & $6.4 \pm 1.4$ & $31.3 \pm 3.6$ & 4.9 \\
\hline $3 \mathbf{a}$ & $30.1 \pm 3.6$ & $176.6 \pm 41.6$ & 5.9 \\
\hline $3 \mathbf{b}$ & $91.6 \pm 0.9$ & $459.6 \pm 83.0$ & 5.0 \\
\hline $4 a$ & $31.5 \pm 5.4$ & $160.9 \pm 20.6$ & 5.1 \\
\hline $4 b$ & $54.3 \pm 8.4$ & $123.4 \pm 16.3$ & 2.3 \\
\hline $5 \mathbf{a}$ & $31.6 \pm 1.9$ & $159.8 \pm 31.0$ & 5.1 \\
\hline $5 b$ & $25.4 \pm 0.2$ & $137.3 \pm 20.9$ & 5.4 \\
\hline $5 c$ & $28.9 \pm 3.6$ & $93.4 \pm 14.6$ & 3.2 \\
\hline
\end{tabular}

is less than the 12.6-fold loss in affinity at LAB brain tissue compared to $\mathrm{HAB}$ brain tissue, the affinity of XBD-173 at LABs (30.3 nM) is almost identical to the affinity at TSPO A17T in this study $(31.3 \mathrm{nM})$. The demonstration that the pharmacodynamic characteristics of both TSPO A147Tdiscriminating and non-discriminating ligands reported on endogenous human cells are mirrored in these novel cell lines verifies their validity for use as a high throughput model for assessment of polymorphism discrimination by TSPO ligands.

\section{Assessment of affinity}

We characterised the affinity of a new TPSO ligand chemotype based on an $N$-alkylated carbazole scaffold in 293T cells over-expressing TSPO WT and A147T (Table 1). 3a bound TSPO WT with an affinity comparable to that of PK 11195. As has been reported for most known second generation TSPO ligands, ${ }^{24,25}$ 3a showed a $6 \times$ loss of affinity at TSPO A147T, similar to the drop off seen in this study with DPA-713 and XBD-173. Changing the $N, N$-diethylamide portion of the scaffold to $N, N$-benzylethylamide (3b) reduced affinity at both TSPO WT and A147T, although the reduction in TSPO A147T affinity (2.6×) was marginally less than at TSPO WT $(3 \times)$ resulting in a slightly reduced level of discrimination between TSPO WT and A147T (5-fold discrimination) when compared to $3 \mathbf{a}$.

Incorporating a bromine atom at the 3 carbon to produce 4a led to a slight increase in affinity for TSPO A147T without impacting affinity at TSPO WT, resulting in a small improvement in discrimination (5-fold discrimination) compared to 3a. Changing the $N, N$-diethylamide portion of the brominated scaffold 4 a to $N, N$-benzylethylamide (4b) again resulted in loss of affinity at TSPO WT (4b has $1.6 \times$ lower affinity than 4a), although the loss of affinity was not as severe as seen with the non-brominated carbazole derivatives $(3 \mathbf{b}$ has $3 \times$ lower affinity than $3 \mathbf{a}$ ). In contrast to the effect seen in the non-brominated carbazoles (3a vs. 3b), the $N, N$ benzylethylamide substitution in the brominated carbazole (4b) improved affinity $1.3 \times$ at TSPO A147T. As a result, compared to $3 \mathrm{a}, \mathbf{4 b}$ showed a reduction in discrimination between TSPO WT and A147T (2.3-fold discrimination). Together, the loss in affinity for TSPO WT when the $N, N$ diethylamide portion of the scaffold is replaced with $N, N$ benzylethylamide suggests that bulk or hydrophobicity in this portion of the scaffold may interfere with interactions with key amino acids in the TSPO WT binding pocket. The observation that bromination of the $N, N$-benzylethylamide scaffold reverses the loss in affinity at TSPO A147T suggests that even though the extra bulk or hydrophobicity may impart steric hindrance, extra substitution of the carbazole through bromination, may allow the molecule to reach the key amino acids in the binding pocket.

The impact of substitution at the 3 carbon of the 3 a $\mathrm{N}, \mathrm{N}$ diethylamide carbazole was further explored by introduction of a freely rotating phenyl in the absence (5a) or presence of 
a methoxy group at the $2^{\prime}(5 \mathbf{b})$ or $4^{\prime}(5 \mathbf{c})$ position on the phenyl ring. These derivatives retained the high affinity for TSPO WT seen with 3a, but showed increased affinity for TSPO A147T. This was particularly pronounced for 5c, with a $2 \times$ higher affinity for TSPO A147T compared to 3a resulting in an improved reduction of discrimination (3.2-fold discrimination). The fifth transmembrane segment of a bacterial homo$\log$ of TSPO A147T is more angled than that of the wild type homolog. ${ }^{27}$ This fifth transmembrane segment contains key binding amino acids, and it could be predicted that the angling of this segment makes the key binding amino acids more difficult to access. Addition of substituents at carbon 3 of the carbazole may allow the molecule to transduce the required distance to access these amino acids. In addition, the substitution of alanine for threonine seen at amino acid residue 147 of TSPO A147T occurs at a key binding amino acid. $^{27,34}$ Alanine is a hydrophobic amino acid, while threonine is a polar amino acid, indicating that a ligand with polar substituents compared to hydrophobic substituents will interact more ideally at this amino acid in TSPO A147T, perhaps explaining the benefit imparted to carbazole affinity by methoxy substitutions. Given these substitutions at carbon 3 of the carbazole were tolerated by TSPO WT, and improved affinity for TSPOA147T, further exploration of substitutions to carbon 3 of $\mathrm{N}$-diethylamide carbazoles may aid in the development of high affinity non-discriminating TSPO ligands.

\section{Functional characterisation}

Pro-apoptotic and anti-proliferative actions are two of the best characterised functions of TSPO ligands. ${ }^{6}$ To explore if TSPO WT and TSPO A147T affinity discrimination was reflected in functional outcomes, we examined the effect of these novel TSPO ligands on the viability and proliferation of 293T cells over-expressing TSPO WT and TSPO A147T. Due to limited solubility of $3 \mathbf{a}, 3 \mathbf{b}, \mathbf{4 b}, \mathbf{4 c}$ and $5 \mathbf{a}$ in aqueous cell culture media, only the functional effect of $\mathbf{3 b}$ and $\mathbf{5 a}$ could be assessed. 5a reduced viability and proliferation with greater potency than PK 11195 and XBD-173 (Fig. 3; Tables 2 and 3). DPA-713 and 3b impaired viability at $100 \mu \mathrm{M}$, but the effect was weak $\left(\mathrm{IC}_{50}>100 \mu \mathrm{M}\right)$ and these compounds did not significantly affect proliferation, even at $100 \mu \mathrm{M}$.

Interestingly, binding sensitivity to TSPO A147T was not reflected in functional assays (Fig. 2; Tables 2 and 3). XBD173 and 5a showed equal viability-reducing and antiproliferative potency at both cell lines despite their 5- to 6-fold drop in affinity to TSPO A147T. Further, the potencies of these compounds are several orders of magnitude less than their TSPO affinities. This could suggest that the functional effects of these ligands on viability and proliferation are not mediated by TSPO. However, the anti-proliferative and viability-reducing effects of PK 11195 can be mitigated by TSPO silencing, ${ }^{35}$ despite the fact that its potency for these functions is several orders of magnitude lower than its affinity for TSPO. ${ }^{35-37}$ Also, a 4-phenyl quinazoline-2-carboxamide with high affinity for the TSPO $\left(K_{\mathrm{i}}=0.5 \mathrm{nM}\right)$ decreased U343 glioblastoma cell viability at micromolar concentrations with-
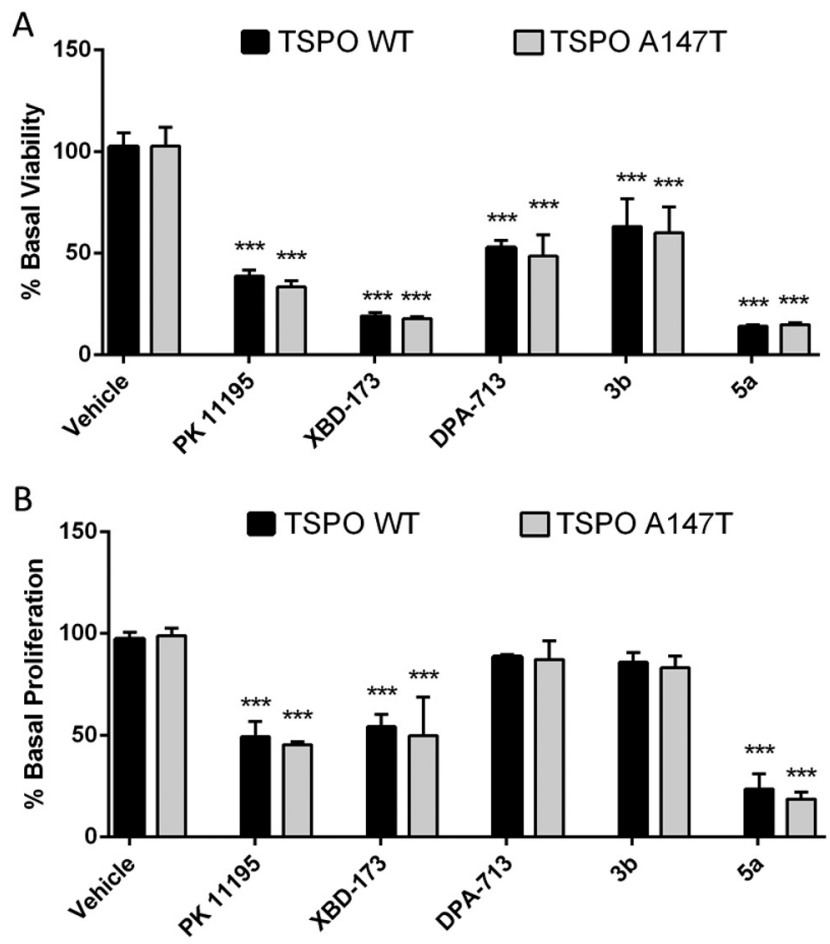

Fig. 3 The effect of carbazole derivatives on (A) viability and (B) proliferation of TSPO WT and A147T over-expressing 293T cells. Both cell lines were treated with drugs $(100 \mu \mathrm{M})$ for $48 \mathrm{~h}$. Cell viability was determined with CellTiter Blue and proliferation was assessed with a BrdU ELISA. Values represent mean \pm SEM ( $n \geq 3$, one-way ANOVA followed by Dunnett's multiple comparison test, $* * * p<0.001 \mathrm{com}-$ pared to vehicle-treated cells).

out off-target activation of G-proteins or inhibiting thirteen protein kinases linked to glioblastoma. ${ }^{38}$ These observations suggest that the common disjunction between TSPO affinity and potency does not necessitate non-specificity. More recently, the duration of time in which a TSPO ligand interacts with the TSPO, as indexed by residence time, has been shown

Table $2 \quad I_{50}$ values for the inhibition of TSPO WT and TSPO A147T over-expressing 293T cell viability

\begin{tabular}{llll}
\hline Compound & $\begin{array}{l}\text { TSPO WT } \\
\mathrm{IC}_{50}(\mu \mathrm{M})\end{array}$ & $\begin{array}{l}\text { TSPO A147T } \\
\mathrm{IC}_{50}(\mu \mathrm{M})\end{array}$ & $\begin{array}{l}\text { TSPO A147T IC } \\
\text { TSPO WT IC }\end{array}$ 50 \\
\hline PK 11195 & $67.4 \pm 10.5$ & $69.15 \pm 2.6$ & 1.0 \\
DPA-713 & $>100$ & $>100$ & $\mathrm{n} / \mathrm{a}$ \\
XBD-173 & $29.5 \pm 3.5$ & $26.2 \pm 3.3$ & 0.9 \\
3b & $>100$ & $>100$ & $\mathrm{n} / \mathrm{a}$ \\
5a & $23.7 \pm 1.0$ & $22.9 \pm 1.1$ & 1.0
\end{tabular}

Table $3 \quad I C_{50}$ values for the inhibition of TSPO WT and TSPO A147T over-expressing 293T cell proliferation

\begin{tabular}{llll}
\hline Compound & $\begin{array}{l}\text { TSPO WT } \\
\mathrm{IC}_{50}(\mu \mathrm{M})\end{array}$ & $\begin{array}{l}\text { TSPO A147T } \\
\mathrm{IC}_{50}(\mu \mathrm{M})\end{array}$ & $\begin{array}{l}\text { TSPO A147T IC } \\
\text { TSPO WT } \mathrm{IC}_{50}\end{array}$ \\
\hline PK 11195 & $>100$ & $>100$ & $\mathrm{n} / \mathrm{a}$ \\
DPA-713 & $>100$ & $>100$ & $\mathrm{n} / \mathrm{a}$ \\
XBD-173 & $>100$ & $>100$ & $\mathrm{n} / \mathrm{a}$ \\
3b & $>100$ & $>100$ & $\mathrm{n} / \mathrm{a}$ \\
5a & $50.5 \pm 5.0$ & $47.1 \pm 1.2$ & 0.9
\end{tabular}


to be a more informative predictor of TSPO potency or efficacy than affinity. A longer residence time correlates with greater functional effects, including more potent viability-impairment. ${ }^{39,40}$ Hence, it may be that while the polymorphism affects affinity, this sensitivity may not be reflected in functional assays as the polymorphism may not affect residence time of the ligands.

\section{Conclusions}

We have established isogenic cell lines stably over-expressing TSPO WT and TSPO A147T, and used this model to explore how structural variants of a novel $\mathrm{N}$-alkylated carbazole scaffold affect affinity to TSPO WT and TSPO A147T. Through substitutions at the carbazole and the $N, N$-diethylamide portion of the molecule, we improved the discrimination of the scaffold from 6-fold (3a) to 2.3-fold (4b). TSPO WT was not as sensitive to substitution at the carbazole as TSPO A147T, and addition of electron-donating groups to the 3-position of the carbazole produced the biggest improvement in TSPO A147T affinity without imparting loss in affinity at TSPO WT (5c). This knowledge can be used to inform further development of TSPO ligands with equally high affinity at TSPO WT and A147T for ultimate use as diagnostic markers for glioblastoma and neuroinflammation.

\section{Experimental section}

\section{Synthesis}

General experimental. All of the solvents and reagents were purchased and used from commercial sources. All reactions were performed under nitrogen, unless otherwise stated. Melting points using an Optimelt Automated melting point apparatus from Stanford Research Systems were measured in open capillary tubes and are uncorrected. IR spectra were recorded neat using a Bruker ALPHA FT-IR spectrometer and peaks are expressed in wavenumbers $\left(\mathrm{cm}^{-1}\right) .{ }^{1} \mathrm{H}$ NMR and ${ }^{13} \mathrm{C}$ NMR spectra were recorded on Bruker Advance DRX 300 Ascend spectrometers at $300 \mathrm{MHz}{ }^{1} \mathrm{H}$ NMR frequency and $75 \mathrm{MHz}{ }^{13} \mathrm{C}$ NMR frequency. $\mathrm{H}$ and $\mathrm{C}$ chemical shifts are expressed as parts per million (ppm). All resonances in the ${ }^{1} \mathrm{H}$ NMR are reported as chemical shift $(\delta)$ and are referenced to the residual chloroform $(7.26 \mathrm{ppm})$; multiplicities are reported as follows: s (singlet), d (doublet), $\mathrm{t}$ (triplet), q (quartet) and $\mathrm{m}$ (multiplet). Coupling constants $(J)$ are reported in $\mathrm{Hz}$. All resonances in the ${ }^{13} \mathrm{C} \mathrm{NMR}$ are reported as chemical shift $(\delta)$ and are referenced to chloroform (77.16).

Elemental microanalysis was obtained from the Department of Chemistry and Biomolecular Sciences at Macquarie University, Australia. Low- and high-resolution mass spectra were obtained through electron ionisation (ESI). Lowresolution mass spectra were performed on a Finnigan LCQ mass spectrometer. High-resolution mass spectra were performed on a Bruker 7T Apex Qe Fourier Transform Ion Cyclotron resonance mass spectrometer equipped with an Apollo II ESI/APCI/MALDI Dual source.
Procedure for the preparation of 3-bromo-9H-carbazole (2). $\mathrm{N}$-Bromosuccinimide ( $23 \mathrm{~g}, 0.13 \mathrm{~mol}, 1.10$ equiv.) was added in parts to a solution of the $9 H$-carbazole $(20 \mathrm{~g}, 0.12 \mathrm{~mol}$, 1.00 equiv.) in DMF $(60 \mathrm{~mL})$ at $0{ }^{\circ} \mathrm{C}$. The reaction was carried out under dark conditions at room temperature for 8 hours. The reaction mixture was poured into ice water and the precipitate was filtered, washed with water and dried under vacuum. Purification by recrystallisation with ethanol gave 2 (23 g, $0.094 \mathrm{mmol}, 76 \%$ ) as a colourless crystalline solid; $\mathrm{R}_{\mathrm{f}}$ 0.88 (ethyl acetate/hexane, $3: 7 \mathrm{v} / \mathrm{v}$ ); m.p $195.4-196.9{ }^{\circ} \mathrm{C} ;{ }^{1} \mathrm{H}$ NMR (300 MHz, $\left.\mathrm{CDCl}_{3}\right) \delta=8.21-8.04(3 \mathrm{H}, \mathrm{m}), 7.54-7.46(3 \mathrm{H}$, $\mathrm{m}), 7.35-7.28$ (2H, m); ${ }^{13} \mathrm{C}$ NMR (75 MHz, $\left.\mathrm{CDCl}_{3}\right) \delta=138.2$, 128.64, 126.58, 123.17, 122.48, 122.21, 121.27, 120.51, 119.93, 112.25, 112.03, 110.79; IR ( $\left.v_{\max } / \mathrm{cm}^{-1}\right): 3401,1563,1434,1053$, 809, 744, 566; MS (+ESI) 248/246 [(M + H $\left.)^{+} 35 / 100 \%\right]$ (found $(+\mathrm{ESI}):[\mathrm{M}+\mathrm{H}]^{+}, \quad 247.9893 / 245.9913 . \mathrm{C}_{12} \mathrm{H}_{9} \mathrm{BrN}^{+}$requires 247.9892/245.9913).

General procedure A. Sodium hydride $(60 \%$ w/w dispersion in mineral oil, 1.50 equiv.) was added portion-wise to a solution of the required carbazole intermediate (1.00 equiv.) in THF $\left(3 \mathrm{~mL} \mathrm{mmol}^{-1}\right)$ at $0{ }^{\circ} \mathrm{C}$. The reaction mixture was then stirred for 30 minutes at room temperature before being cooled to $0^{\circ} \mathrm{C}$.

The required alkylating agent (1.50 equiv.) was added at $0{ }^{\circ} \mathrm{C}$ and the mixture was warmed to room temperature and stirred for an additional 1 hour. The reaction mixture was poured into ice water and neutralised with aqueous hydrochloric acid ( $1 \mathrm{M}$ ). The organic layer was collected and the aqueous layer was extracted with ethyl acetate $(3 \times)$. The organic layers were combined, dried over anhydrous $\mathrm{MgSO}_{4}$, filtered, and the solvent was removed in vacuo. Purification by flash chromatography on silica gave the desired product.

2-(9H-Carbazol-9-yl)-N,N-diethylacetamide (3a). General procedure A was followed with $9 H$-carbazole $(300 \mathrm{mg}, 1.79$ mmol, 1.00 equiv.) and 2-bromo- $N, N$-diethylacetamide $(369 \mu \mathrm{L}$, 2.69 mmol, 1.50 equiv.). Purification by flash chromatography (silica, ethyl acetate/hexane, $3: 7 \mathrm{v} / \mathrm{v}$ ) gave $3 a(460 \mathrm{mg}, 1.64$ mmol, 90\%) as a colourless powder. $\mathrm{R}_{\mathrm{f}} \mathbf{0 . 4 3}$ (ethyl acetate/ hexane, $3: 7 \mathrm{v} / \mathrm{v})$; m.p 138.7-139.9 ${ }^{\circ} \mathrm{C} ;{ }^{1} \mathrm{H}$ NMR $(300 \mathrm{MHz}$, $\left.\mathrm{CDCl}_{3}\right) \delta=8.10-8.07$ (2H, d), 7.46-7.20 (6H, m), $5.02(2 \mathrm{H}, \mathrm{s})$, 3.40-3.34 (4H, q, $J=6.45), 1.28-1.05(6 \mathrm{H}, \mathrm{t}, J=6.45) ;{ }^{13} \mathrm{C} \mathrm{NMR}$ $\left(75 \mathrm{MHz}, \mathrm{CDCl}_{3}\right) \delta=166.29,140.72,125.90,123.17,120.38$, 119.38, 108.52, 45.50, 41.63, 14.39, 14.21; IR $\left(v_{\max } / \mathrm{cm}^{-1}\right) 2970$, 1653, 1464, 1248, 799; MS (+ESI) $583\left[(2 \mathrm{M}+\mathrm{Na})^{+} 17 \%\right], 303[(\mathrm{M}$ $\left.+\mathrm{Na})^{+} 45 \%\right], 281\left[(\mathrm{M}+\mathrm{H})^{+} 100 \%\right]$; found: C, 78.29; H, 6.52; N, 8.11. Calc for $\mathrm{C}_{18} \mathrm{H}_{20} \mathrm{~N}_{2} \mathrm{O}$ : C, 78.11; H, 6.59; N, 8.11\%.

$\mathrm{N}$-Benzyl-2-(9H-carbazol-9-yl)-N-ethylacetamide (3b). General procedure A was followed with $9 H$-carbazole $(300 \mathrm{mg}, 1.79$ mmol, 1.00 equiv.) $\mathrm{N}$-benzyl-2-bromo- $\mathrm{N}$-ethylacetamide (530 $\mu \mathrm{L}, \quad 2.69$ mmol, 1.50 equiv.). Purification by flash chromatography (ethyl acetate/hexane, $1: 4 \mathrm{v} / \mathrm{v}$ ) gave $3 \mathrm{~b}$ (530 $\mathrm{mg}, 1.55 \mathrm{mmol}, 86 \%$ ) as a colourless powder. The ${ }^{1} \mathrm{H}$ NMR spectrum of this amide shows the presence of two different rotamers in a 1:1 ratio. For the sake of simplification, the NMR data for only one rotamer is reported. $R_{f} 0.70$ (ethyl acetate/hexane, $3: 7 \mathrm{v} / \mathrm{v})$; m.p 144.2-145.6 ${ }^{\circ} \mathrm{C} ;{ }^{1} \mathrm{H}$ NMR (300 
$\left.\mathrm{MHz} \mathrm{CDCl}_{3}\right) \delta=8.11-8.02(2 \mathrm{H}, \mathrm{m}), 7.46-7.16(11 \mathrm{H}, \mathrm{m}), 4.99$ (2H, s), 4.62 (2H, s), 3.37-3.34 (2H, q), 1.06-1.02 (3H, t); ${ }^{13} \mathrm{C}$ NMR (75 $\left.\mathrm{MHz}, \mathrm{CDCl}_{3}\right) \delta=169.10,140.75,128.62,128.29$, 125.95, 125.95, 121.75, 120.47, 119.49, 115.42, 108.46, 49.83, 48.67, 43.11, 13.25; IR $\left(v_{\max } / \mathrm{cm}^{-1}\right) 3402,1658,1536,1452$, 799; MS (+ESI) $365\left[(\mathrm{M}+\mathrm{Na})^{+} 40 \%\right], 343\left[(\mathrm{M}+\mathrm{H})^{+} 100 \%\right]$; found: $\mathrm{C}, 80.55 ; \mathrm{H}, 6.49 ; \mathrm{N}, 8.19$. Calc for $\mathrm{C}_{23} \mathrm{H}_{22} \mathrm{~N}_{2} \mathrm{O}$ : C, 80.67 ; H, 6.48; N, 8.18\%.

2-(3-Bromo-9H-carbazole-9-yl)-N,N-diethylacetamide (4a). General procedure A was followed with $2(2.00 \mathrm{~g}, 8.13 \mathrm{mmol}$, 1.00 equiv.) and 2-bromo- $N, N$-diethylacetamide $(1.70 \mathrm{~mL}$, 12.19 mmol, 1.50 equiv.). Purification by flash chromatography (ethyl acetate/hexane, $3: 7 \mathrm{v} / \mathrm{v})$ gave $4 \mathrm{a}(2.72$ $\mathrm{g}, 8.13 \mathrm{mmol}, 93 \%$ ) as a colourless powder. $\mathrm{R}_{\mathrm{f}} 0.38$ (ethyl acetate/hexane, $3: 7 \mathrm{v} / \mathrm{v})$; m.p $133.8-135.2{ }^{\circ} \mathrm{C}$; ${ }^{1} \mathrm{H}$ NMR (300 $\left.\mathrm{MHz}, \mathrm{CDCl}_{3}\right) \delta=8.17(1 \mathrm{H}, \mathrm{s}) \mathbf{8 . 0 3}^{-8.00}(1 \mathrm{H}, \mathrm{m}), 7.51-7.43$ (1H, m), 7.33-7.16 (4H, m), $4.95(2 \mathrm{H}, \mathrm{s}), 3.40-3.35(4 \mathrm{H}, \mathrm{q}, J=$ 7.05), 1.42-1.10 (6H, t, $J=7.05$ ); ${ }^{13} \mathrm{C} \mathrm{NMR}$ (75 $\left.\mathrm{MHz}, \mathrm{CDCl}_{3}\right) \delta$ $=165.8,141.03,139.46,128.51,126.65,124.94,123.13$, $122.15,120.63,119.83,112.25,110.08,108.65,45.34,41.62$, 12.95; IR $\left(v_{\max } / \mathrm{cm}^{-1}\right) 2925,1642,1426,1268,739,564$; MS (+ESI) $741 / 739\left[(2 \mathrm{M}+\mathrm{Na})^{+} 5 / 20 \%\right], 383 / 381\left[(\mathrm{M}+\mathrm{Na})^{+} 40 /\right.$ $100 \%]$; found: $\mathrm{C}, 60.26 ; \mathrm{H}, 5.10 ; \mathrm{N}, 7.88$. Calc for $\mathrm{C}_{18} \mathrm{H}_{19} \mathrm{BrN}_{2} \mathrm{O}: \mathrm{C}, 60.18 ; \mathrm{H}, 5.33 ; \mathrm{N}, 7.80 \%$.

$\mathrm{N}$-Benzyl-2-(3-bromo-9H-carbazol-9-yl)-N-ethylacetamide (4b). General procedure A was followed with 2 (1.00 g, 4.06 mmol, 1.00 equiv.) and $N$-benzyl-2-bromo- $N$-ethylacetamide (1.20 mL, $6.09 \mathrm{~mL}, 1.50$ equiv.). Purification by flash chromatography (ethyl acetate/hexane, $1: 4 \mathrm{v} / \mathrm{v}$ ) gave $4 \mathrm{~b}(1.38$ $\mathrm{mg}, 3.28 \mathrm{mmol}, 81 \%$ ) as a colourless powder. The ${ }^{1} \mathrm{H}$ NMR spectrum of this amide shows the presence of two different rotamers in a 1:1 ratio. For the sake of simplification, the NMR data for only one rotamer is reported. $\mathbf{R}_{\mathrm{f}} \mathbf{0 . 6 0}$ (ethyl acetate/ hexane, $3: 7 \mathrm{v} / \mathrm{v})$; m.p 121.9-123.44 ${ }^{\circ} \mathrm{C}$; ${ }^{1} \mathrm{H}$ NMR $(300 \mathrm{MHz}$, $\left.\mathrm{CDCl}_{3}\right) \delta=8.08-8.01(1 \mathrm{H}, \mathrm{m}), 7.94-7.85(1 \mathrm{H}, \mathrm{m}), 7.40-7.01(9 \mathrm{H}$, $\mathrm{m}), 6.89-6.86(1 \mathrm{H}, \mathrm{m}), 4.77(2 \mathrm{H}, \mathrm{s}), 4.52(2 \mathrm{H}, \mathrm{s}), 3.43-3.24(2 \mathrm{H}$, q), $1.14-0.98(3 \mathrm{H}, \mathrm{t}) ;{ }^{13} \mathrm{C}$ NMR (75 MHz, $\left.\mathrm{CDCl}_{3}\right) \delta=166.81$, $141.07,139.47,129.20,128.67,128.30,126.35$, 125.92, 124.94, $123.17,123.03,122.14,120.66,119.75,110.03,108.65,108.47$, 50.12, 44.98, 42.41, 13.71; IR $\left(v_{\max } / \mathrm{cm}^{-1}\right)$ 1645, 1450, 1263, 817, 718, 588; MS (+ESI) 865/863 [(2M + Na $\left.)^{+} 10 / 25 \%\right], 445 / 443[(\mathrm{M}+$ $\left.\mathrm{Na})^{+} 35 / 100 \%\right]$; found: C, 65.24; $\mathrm{H}, 5.14 ; \mathrm{N}, 6.41$. Calc for $\mathrm{C}_{23} \mathrm{H}_{21} \mathrm{BrN}_{2} \mathrm{O}$ : C, 65.57; $\mathrm{H}, 5.02 ; \mathrm{N}, 6.65 \%$.

General procedure B. $4 \mathrm{a}$ (1.00 equiv.), the boronic acid derivative, (1.5 equiv.), $\left[\mathrm{Pd}\left(\mathrm{PPh}_{3}\right)_{4}\right](5 \mathrm{~mol} \%)$ and $\mathrm{Cs}_{2} \mathrm{CO}_{3}(2.00$ equiv.) were combined in toluene $(5 \mathrm{~mL})$. The reaction mixture was purged with argon, sealed with a rubber septum and stirred at $95{ }^{\circ} \mathrm{C}$ for 24 hours. The reaction mixture was cooled to room temperature and filtered through a Celite ${ }^{\mathrm{TM}}$ plug and eluted with ethyl acetate. The crude mixture was diluted with water $(5 \mathrm{~mL})$ and the organic layer was extracted. The aqueous layer was further extracted with ethyl acetate $(3 \times 5$ $\mathrm{mL}$ ). The combined organic layers were then dried over anhydrous $\mathrm{MgSO}_{4}$, filtered and the solvent removed in vacuo. The crude residue was then purified by flash chromatography on silica to afford the desired product.
N,N-Diethyl-2-(3-phenyl-9H-carbazole-9-yl)acetamide

(5a). General procedure B was followed using $4 \mathrm{a}(200 \mathrm{mg}, 0.579$ mmol, 1.00 equiv.) and phenylboronic acid (102 mg, 0.835 mmol, 1.50 equiv.). Purification by flash chromatography (ethyl acetate/hexane, $3: 7 \mathrm{v} / \mathrm{v})$ gave $5 \mathrm{a}(137 \mathrm{mg}, 0.384 \mathrm{mmol}$, $69 \%$ ) as a colourless solid. $\mathrm{R}_{\mathrm{f}} 0.38$ (ethyl acetate/hexane, $3: 7$ v/v); m.p 94.3-95.6 ${ }^{\circ} \mathrm{C}$; ${ }^{1} \mathrm{H}$ NMR (300 $\left.\mathrm{MHz}, \mathrm{CDCl}_{3}\right) \delta=8.22-$ 8.21 (1H, m), 8.06-8.00 (1H, m), 7.63-7.59 (2H, m), 7.41-7.15 $(8 \mathrm{H}, \mathrm{m}), 4.95(2 \mathrm{H}, \mathrm{s}), 3.37-3.27$ (4H, q, $J=7.04), 1.08-0.97$ $(6 \mathrm{H}, \mathrm{t}, J=7.05) ;{ }^{13} \mathrm{C}$ NMR (75 MHz, $\left.\mathrm{CDCl}_{3}\right) \delta=166.20,142.14$, 141.21, 140.30, 132.96, 127.32, 126.11, 125.92, 125.50, 123.71, 123.35, 120.49, 119.56, 119.41, 118.98, 108.78, 108.64, 45.55, 41.65, 12.97; IR $\left(v_{\max } / \mathrm{cm}^{-1}\right)$ 2969, 1650, 1217, 768, 573; MS $(+\mathrm{ESI}) 735\left[(2 \mathrm{M}+\mathrm{Na})^{+} 20 \%\right], 379\left[(\mathrm{M}+\mathrm{Na})^{+} 100 \%\right], 357[(\mathrm{M}+$ $\mathrm{H})^{+} 10 \%$; found: $\mathrm{C}, 80.82 ; \mathrm{H}, 6.74 ; \mathrm{N}, 7.89$. Calc for $\mathrm{C}_{24} \mathrm{H}_{24} \mathrm{~N}_{2} \mathrm{O}$ : C, 80.87; H, 6.79; N, 7.86\%.

$\mathrm{N}, \mathrm{N}$-Diethyl-2-(3-(2-methoxyphenyl)-9H-carbazol-9-yl)acetamide (5b). General procedure B was followed using 4 a (200 $\mathrm{mg}, 0.557$ mmol, 1.00 equiv.) and 2-methoxyphenylboronic acid $(127 \mathrm{mg}$, $0.835 \mathrm{mmol}, 1.50$ equiv.). Purification by flash chromatography (ethyl acetate/hexane, $3: 7 \mathrm{v} / \mathrm{v}$ ) gave $\mathbf{5 b}$ as a colourless powder (156 mg, $0.404 \mathrm{mmol}, 73 \%$ ). $\mathrm{R}_{\mathrm{f}} 0.32$ (ethyl acetate/hexane, $3: 7$ v/v) m.p 148.1-150.6 ${ }^{\circ} \mathrm{C}$; ${ }^{1} \mathrm{H}$ NMR (300 MHz, $\left.\mathrm{CDCl}_{3}\right) \delta=8.22$ (1H, s), 8.01-8.08 (1H, m), 7.64-7.61 (1H, m), 7.46-7.20 (7H, m), 7.08-6.84 (1H, m), 5.03 (2H, s), 3.82 (3H, s), 3.43-3.39 (4H, q, $J$ = 6.90), 1.16-1.10 (6H, q, $\left.J=6.90) ;{ }^{13} \mathrm{C} \mathrm{NMR} \mathrm{(75} \mathrm{MHz,} \mathrm{CDCl}_{3}\right) \delta$ $=166.31,156.67,141.09,139.93,131.61,131.31,129.91,128.02$, $127.86,125.85,123.47,123.13,121.41,120.89,120.46,119.39$, 111.39, 108.54, 107.95, 55.67, 45.62, 41.44, 14.20; IR $\left(v_{\max } / \mathrm{cm}^{-1}\right)$ 2963, 1638, 1463, 1219, 1022, 749; MS (+ESI) $795\left[(2 \mathrm{M}+\mathrm{Na})^{+}\right.$ 25\%], $409\left[(\mathrm{M}+\mathrm{Na})^{+} 100 \%\right], 387\left[(\mathrm{M}+\mathrm{H})^{+}\right.$15\%]; found: $\mathrm{C}$, 77.72; H, 6.88; N, 7.21. Calc for $\mathrm{C}_{25} \mathrm{H}_{26} \mathrm{~N}_{2} \mathrm{O}_{2}$ : C, 77.69; H, 6.78; $\mathrm{N}, 7.25 \%$.

$\mathrm{N}, \mathrm{N}$-Diethyl-2-(3-(4-methoxyphenyl)-9H-carbazole-9$y$ l)acetamide (5c). General procedure B was followed using $4 \mathrm{a}$ (500 mg, $1.39 \mathrm{mmol}, 1.00$ equiv.) and 4-methoxyphenylboronic acid (317 mg, $2.086 \mathrm{mmol}, 1.50$ equiv.). Purification by flash chromatography (ethyl acetate/hexane, $3: 7 \mathrm{v} / \mathrm{v}$ ) gave $5 \mathrm{c}$ as a colourless powder (392 mg, $1.014 \mathrm{mmol}, 73 \%$ ). $\mathrm{R}_{\mathrm{f}} 0.28$ (ethyl acetate/hexane, $3: 7 \mathrm{v} / \mathrm{v})$; m.p $119.8-121.2{ }^{\circ} \mathrm{C} ;{ }^{1} \mathrm{H}$ NMR (300 $\left.\mathrm{MHz} \mathrm{CDCl}_{3}\right) \delta=8.26(1 \mathrm{H}, \mathrm{s}), 8.16-8.13(1 \mathrm{H}, \mathrm{m}), 7.68-7.63(3 \mathrm{H}$, m), 7.51-7.25 (4H, m), 7.05-7.02 (2H, m), $5.10(2 \mathrm{H}, \mathrm{s}), 4.90(3 \mathrm{H}$, s), 3.46-3.42 (4H, t, $J=7.05), 1.19-1.12(6 \mathrm{H}, \mathrm{t}, J=7.05) .{ }^{13} \mathrm{C}$ NMR (75 MHz, $\left.\mathrm{CDCl}_{3}\right) \delta=166.26,158.60,141.17,139.94$, 134.80, 132.66, 128.28, 126.05, 125.25, 123.69, 123.34, 120.48, 119.48, 118.53, 114.21, 108.73, 108.60, 55.40, 45.62, 41.66, 12.98; IR $\left(v_{\max } / \mathrm{cm}^{-1}\right)$ 2932, 1658, 1476, 1260, 1216, 1033, 750, 524; MS (+ESI) $795\left[(2 \mathrm{M}+\mathrm{Na})^{+} 25 \%\right], 409\left[(\mathrm{M}+\mathrm{Na})^{+} 100 \%\right], 387[(\mathrm{M}+$ $\mathrm{H})^{+} 15 \%$; found: $\mathrm{C}, 77.60 ; \mathrm{H}, 6.85 ; \mathrm{N}, 7.18$. Calc for $\mathrm{C}_{25} \mathrm{H}_{26} \mathrm{~N}_{2} \mathrm{O}_{2}$ : C, 77.69; H, 6.78; N, 7.25\%.

\section{Biological methods}

Establishment of cell lines. In brief, transfer of genetic material was performed with lentivirus containing either human TSPO WT or A147T cDNA, and a puromycin-resistance 
gene (Addgene, MA, USA). Cells expressing introduced genetic material were selected using puromycin.

Lentivirus-producing constructs were generated using the Gateway ${ }^{\circledR}$ cloning system (Life Technologies) according to the manufacturer's instructions. Constructs were first cloned into the $\mathrm{pENTR}^{\mathrm{TM}} / \mathrm{SD} / \mathrm{D}-\mathrm{TOPO}{ }^{\circledR}$ entry vector and subsequently into the destination vector, pLVX-V5 (ref. 41) using Gateway ${ }^{\circledR}$ LR Clonase II ${ }^{\circledR}$ enzyme. All clones were sequenced to verify the correct insertion and sequence. TSPO WT CDNA was amplified by PCR with the $5^{\prime}$ oligonucleotide forward primer 5'-ATGGCCCCGCCCTGGGTGC-3' and reverse primer 5'-CTCTGGCAGCCGCCGTCCC-3'. The A147T mutant was produced as previously described using the QuikChange Sitedirected Mutagenesis Kit protocol (Agilent) with the forward primer 5'-CTGGCCTGGCTGGCCTTCACGACCACACTCAACTACTGC-3' and reverse primer 5'-GCAGTAGTTGAGTGTGGTCGTGAAGGCCAGCCAGGCCAG-3'. ${ }^{42}$ Lentivirus production for generation of stable TSPO WT or A147T-expressing cell lines was conducted as previously described. ${ }^{43} 293 \mathrm{~T}$ cells were cultured in DMEM containing $10 \%$ fetal bovine serum, $100 \mathrm{U} \mathrm{ml}^{-1}$ penicillin/streptomycin and $2 \mathrm{mM}$ glutamine. Seven days after infection with lentiviruses, cells were selected for expression using puromycin.

Western blotting. Western blotting was performed to confirm expression of stably over-expressing TSPO WT or A147T using previously described methods. ${ }^{44}$ Primary antibodies were to human TSPO (Abcam); V5 (Life Technologies) and GAPDH (Millipore). Horseradish peroxidase-coupled secondary antibodies (Santa Cruz) were used. Western blots were detected on a ChemiDoc imaging system (BioRad) and quantified using Fiji software. ${ }^{45}$

Immunofluorescence and confocal microscopy. Cells were cultured on coverslips and fixed with $4 \%$ paraformaldehyde. Cells were permeabilised with $0.2 \% \quad$ NP-40 and counterstained for V5 (Life Technologies) and the mitochondria marker ATPB (Abcam). Nuclei were visualized with DAPI. Secondary antibodies (Invitrogen) were coupled with the fluorochromes Alexa Fluor 488 or 568. Confocal images were taken on the Zeiss LSM 880 microscope using the C-Apochromat 40×/1.1 water objective. Any contrast enhanced adjustments to remove dim structures and non-specific signal was uniformly applied to all images. ${ }^{46}$

Membrane preparation. Transfected 293T cells were incubated with PBS containing 0.04\% EDTA (pH 7.4) at $37{ }^{\circ} \mathrm{C}$ for $10 \mathrm{~min}$. Cells were spun at $1000 \mathrm{~g}$ for $10 \mathrm{~min}$ and the pellet was suspended in $3 \mathrm{ml}$ of ice-cold Tris-HCl $(5 \mathrm{mM}), \mathrm{pH}$ 7.4. Pellets were homogenised (Ultra-Turrax homogeniser; IKA Werke, Staufen, Germany) and centrifuged at $48000 \mathrm{~g}$ at $4{ }^{\circ} \mathrm{C}$ for $15 \mathrm{~min}$. The obtained pellet was re-suspended in 10 $\mathrm{ml}$ Tris-HCl (50 mM; pH 7.4) and centrifuged at $48000 \mathrm{~g}$ for $15 \mathrm{~min}$ at $4{ }^{\circ} \mathrm{C}$. The pellet was resuspended in $10 \mathrm{ml}$ of Tris$\mathrm{HCl}$ (50 mM; pH 7.4) and spun at $48000 \mathrm{~g}$ for $15 \mathrm{~min}$, at $4^{\circ} \mathrm{C}$. The resulting pellet was resuspended in $6 \mathrm{ml}$ Tris-HCl (50 $\mathrm{mM}$; $\mathrm{pH}$ 7.4) and total protein concentration was determined using the BCA protein assay (Pierce Biotechnology Inc., Rockford, IL) according to the manufacturer's protocol.
Saturation radioligand binding. Membranes $(20 \mu \mathrm{g}$ per well diluted in $50 \mathrm{mM}$ Tris- $\mathrm{HCl}, \mathrm{pH}$ 7.4) were incubated with $\left[{ }^{3} \mathrm{H}\right]$ PK 11195 (Perkin-Elmer, Beaconsfield, UK) at seven concentrations (0.1-25 nM), $3 \mu \mathrm{M}$ unlabelled PK 11195 (SigmaAldrich) to determine non-specific binding, or a vehicle control $(0.1 \%$ DMSO) $(\mathrm{v} / \mathrm{v})$ to determine total binding. The reaction was incubated for $90 \mathrm{~min}$ at $4{ }^{\circ} \mathrm{C}$ to achieve equilibrium, terminated by rapid filtration through a glass-fibre filter (GF/ C; Millipore, Carrigtwonhill, Ireland) and washed with 50 $\mathrm{mM}$ Tris- $\mathrm{HCl}(\mathrm{pH} 7.4)$ at $4{ }^{\circ} \mathrm{C}$. The filters were allowed to dry overnight, covered with Microscint-0 scintillation cocktail (Perkin-Elmer) and radioactivity measured with a Microbeta ${ }^{2}$ 2450 Microplate Counter (Perkin-Elmer). Saturation binding was analysed with Graphpad Prism 6.0 (Graphpad, La Jolla, CA) using a non-linear regression curve fit to determine the $K_{\mathrm{d}}$. Data are expressed as mean \pm SEM from at least three independent experiments.

Competition radioligand binding. Membranes $(20 \mu \mathrm{g}$ per well diluted in $50 \mathrm{mM}$ Tris- $\mathrm{HCl}, \mathrm{pH}$ 7.4) were incubated with $\sim K_{\mathrm{d}}$ concentration of $\left[{ }^{3} \mathrm{H}\right] \mathrm{PK} 11195(10 \mathrm{nM})$ and test compounds $(0.3 \mathrm{nM}-10 \mu \mathrm{M})$ in a final volume of $200 \mu \mathrm{L}$ for $90 \mathrm{~min}$ at $4{ }^{\circ} \mathrm{C}$. To determine total binding, $\left[{ }^{3} \mathrm{H}\right] \mathrm{PK}$ 11195 and membranes were incubated with vehicle alone (0.1\% DMSO (v/v) in $50 \mathrm{mM}$ Tris- $\mathrm{HCl}, \mathrm{pH} 7.4)$. Non-specific binding was determined in the presence of a saturating concentration of cold PK $11195(3 \mu \mathrm{M})$, and amounted to 5-15\% of total binding. After incubation, assays were terminated by rapid filtration through a 96-well glass-fibre filter plate (Millipore) and washed 8 times with ice-cold $50 \mathrm{mM}$ Tris-HCl (pH 7.4) using a Brandel 96-sample vacuum harvester. The filter was covered with MicroScint 0 scintillation cocktail (Perkin Elmer) and radioactivity counted using a Microbeta $^{2} 2450$ Microplate Counter (Perkin Elmer). Data were corrected for non-specific binding and expressed as a percentage of vehicle control. Data were analysed using Graphpad Prism 6.0 (Graphpad) and a four-parameter nonlinear regression curve fit to calculate the $K_{\mathrm{i}}$ values. Data are expressed as mean \pm SEM from at least three independent experiments.

Cell viability. We used the metabolism of resazurin to the fluorescent resorufin to deduce the proportion of viable cells after exposure to compounds. Transfected 293 T cells $(8.75 \times$ $10^{3}$ cells per well) were seeded onto poly-L-lysine-coated (100 $\mu \mathrm{g} \mathrm{ml}^{-1}$ ) 96-well plates and treated on the following day with vehicle or test compounds (1-100 $\mu \mathrm{M})$ for $48 \mathrm{~h}$. CellTiter Blue reagent $(20 \mu \mathrm{L}$; Promega, Madison, WI) was added to each well at $37{ }^{\circ} \mathrm{C}$ for $4 \mathrm{~h}$. The supernatant $(100 \mu \mathrm{L})$ was transferred to a black-well plate and fluorescence was measured with a POLARstar Omega plate reader (BMG Labtech, Durham, NC) at Ex560/Em590 nm. Data were normalised to vehicle controls and $\mathrm{IC}_{50}$ values calculated by non-linear regression analysis using Graphpad Prism 6.0 (Graphpad). IC $_{50}$ values represent mean \pm SEM from 3 independent experiments. Statistical significance was assessed with a one-way ANOVA with Dunnett's multiple comparison's test. $p<0.05$ was considered statistically significant. 
BrdU ELISA. Incorporation of 5-bromo-2'-deoxyuridine (BrdU) into DNA as cells replicate was used as an index of proliferation. Transfected $293 \mathrm{~T}$ cells $\left(8.75 \times 10^{3}\right.$ cells per well $)$ were seeded onto poly-L-lysine-coated $\left(100 \mu \mathrm{g} \mathrm{ml}{ }^{-1}\right)$ 96-well plates and treated on the following day with vehicle or test compounds (1-100 $\mu \mathrm{M})$ for $48 \mathrm{~h}$. Cells were incubated with $10 \mu \mathrm{L}$ of BrdU (1:100; Roche Molecular Diagnostics Indianapolis, IN) at $37^{\circ} \mathrm{C}$ for $4 \mathrm{~h}$. Detection of BrdU incorporated into DNA of proliferating cells was performed with a BrdU ELISA (Roche Molecular Diagnostics) following the manufacturer's instructions. The reaction was stopped with $1 \mathrm{M}$ sulfuric acid and the absorbance was measured with a POLARstar Omega plate reader (BMG Labtech) at $450 \mathrm{~nm}$. Data were normalised to vehicle controls and $\mathrm{IC}_{50}$ values calculated by non-linear regression analysis using Graphpad Prism 6.0 (Graphpad). $\mathrm{IC}_{50}$ values represent mean \pm SEM from 3 independent experiments. Statistical significance was assessed with a one-way ANOVA with Dunnett's multiple comparison's test. $p<0.05$ was considered statistically significant.

\section{Acknowledgements}

We wish to acknowledge Dr Donna Lai and Dr Sheng Hua for assistance with use of the Bosch Molecular Biology Facility's equipment. Work performed was supported in part by the European Union's Seventh Framework Programme [FP7/20072013] INMiND (Grant agreement No. HEALTH-F2-2011278850).

\section{References}

1 V. Papadopoulos, M. Baraldi, T. R. Guilarte, T. B. Knudsen, J. J. Lacapere, P. Lindemann, M. D. Norenberg, D. Nutt, A. Weizman, M. R. Zhang and M. Gavish, Trends Pharmacol. Sci., 2006, 27, 402-409.

2 V. Papadopoulos, H. Amri, N. Boujrad, C. Cascio, M. Culty, M. Garnier, M. Hardwick, H. Li, B. Vidic, A. S. Brown, J. L. Reversa, J. M. Bernassau and K. Drieu, Steroids, 1997, 62, 21-28.

3 S. Taketani, H. Kohno, T. Furukawa and R. Tokunaga, J. Biochem., 1995, 117, 875-880.

4 R. B. Banati, R. J. Middleton, R. Chan, C. R. Hatty, W. WaiYing Kam, C. Quin, M. B. Graeber, A. Parmar, D. Zahra, P. Callaghan, S. Fok, N. R. Howell, M. Gregoire, A. Szabo, T. Pham, E. Davis and G. J. Liu, Nat. Commun., 2014, 5, 5452.

5 A. H. Zhao, L. N. Tu, C. Mukai, M. P. Sirivelu, V. V. Pillai, K. Morohaku, R. Cohen and V. Selvaraj, J. Biol. Chem., 2016, 291, 1591-1603.

6 E. L. Werry, M. L. Barron and M. Kassiou, Biochem. Soc. Trans., 2015, 43, 531-536.

7 H. Miettinen, J. Kononen, H. Haapasalo, P. Helen, P. Sallinen, T. Harjuntausta, H. Helin and H. Alho, Cancer Res., 1995, 55, 2691-2695.

8 N. Miyazawa, E. Hamel and M. Diksic, J. Neuro-Oncol., 1998, 38, 19-26.

9 E. Vlodavsky and J. F. Soustiel, J. Neuro-Oncol., 2007, 81, 1-7.
10 M. Wang, X. Wang, L. Zhao, W. Ma, I. R. Rodriguez, R. N. Fariss and W. T. Wong, J. Neurosci., 2014, 34, 3793-3806.

11 A. M. Dickens, S. Vainio, P. Marjamaki, J. Johansson, P. Lehtiniemi, J. Rokka, J. Rinne, O. Solin, M. HaaparantaSolin, P. A. Jones, W. Trigg, D. C. Anthony and L. Airas, J. Nucl. Med., 2014, 55, 466-472.

12 S. Lavisse, M. Guillermier, A. S. Herard, F. Petit, M. Delahaye, N. Van Camp, L. Ben Haim, V. Lebon, P. Remy, F. Dolle, T. Delzescaux, G. Bonvento, P. Hantraye and C. Escartin, J. Neurosci., 2012, 32, 10809-10818.

13 J. Maeda, M. Higuchi, M. Inaji, B. Ji, E. Haneda, T. Okauchi, M. R. Zhang, K. Suzuki and T. Suhara, Brain Res., 2007, 1157, 100-111.

14 Y. Y. Cheung, M. L. Nickels, D. Tang, J. R. Buck and H. C. Manning, Bioorg. Med. Chem. Lett., 2014, 24, 4466-4471.

15 D. Tang, M. L. Nickels, M. N. Tantawy, J. R. Buck and H. C. Manning, Mol. Imaging Biol., 2014, 16, 813-820.

16 B. Gulyas, B. Makkai, P. Kasa, K. Gulya, L. Bakota, S. Varszegi, Z. Beliczai, J. Andersson, L. Csiba, A. Thiele, T. Dyrks, T. Suhara, K. Suzuki, M. Higuchi and C. Halldin, Neurochem. Int., 2009, 54, 28-36.

17 B. Janssen, D. J. Vugts, U. Funke, G. T. Molenaar, P. S. Kruijer, B. N. van Berckel, A. A. Lammertsma and A. D. Windhorst, Biochim. Biophys. Acta, 2016, 1862, 425-441.

18 S. Pappata, P. Cornu, Y. Samson, C. Prenant, J. Benavides, B. Scatton, C. Crouzel, J. J. Hauw and A. Syrota, J. Nucl. Med., 1991, 32, 1608-1610.

19 P. Jensen, L. Feng, I. Law, C. Svarer, G. M. Knudsen, J. D. Mikkelsen, R. de Nijs, V. A. Larsen, A. Dyssegaard, G. Thomsen, W. Fischer, D. Guilloteau and L. H. Pinborg, J. Nucl. Med., 2015, 56, 1386-1390.

20 J. H. Vera, Q. Guo, J. H. Cole, A. Boasso, L. Greathead, P. Kelleher, E. A. Rabiner, N. Kalk, C. Bishop, R. N. Gunn, P. M. Matthews and A. Winston, Neurology, 2016, 86, 1425-1432.

21 M. Politis, N. Lahiri, F. Niccolini, P. Su, K. Wu, P. Giannetti, R. I. Scahill, F. E. Turkheimer, S. J. Tabrizi and P. Piccini, Neurobiol. Dis., 2015, 83, 115-121.

22 L. D. Gershen, P. Zanotti-Fregonara, I. H. Dustin, J. S. Liow, J. Hirvonen, W. C. Kreisl, K. J. Jenko, S. K. Inati, M. Fujita, C. L. Morse, C. Brouwer, J. S. Hong, V. W. Pike, S. S. Zoghbi, R. B. Innis and W. H. Theodore, JAMA Neurol., 2015, 72, 882-888.

23 C. M. Sandiego, J. D. Gallezot, B. Pittman, N. Nabulsi, K. Lim, S. F. Lin, D. Matuskey, J. Y. Lee, K. C. O'Connor, Y. Huang, R. E. Carson, J. Hannestad and K. P. Cosgrove, Proc. Natl. Acad. Sci. U. S. A., 2015, 112, 12468-12473.

24 D. R. Owen, A. J. Lewis, R. Reynolds, R. Rupprecht, D. Eser, M. R. Wilkins, I. Bennacef, D. J. Nutt and C. A. Parker, Synapse, 2011, 65, 257-259.

25 D. R. Owen, R. N. Gunn, E. A. Rabiner, I. Bennacef, M. Fujita, W. C. Kreisl, R. B. Innis, V. W. Pike, R. Reynolds, P. M. Matthews and C. A. Parker, J. Nucl. Med., 2011, 52, 24-32.

26 D. R. Owen, A. J. Yeo, R. N. Gunn, K. Song, G. Wadsworth, A. Lewis, C. Rhodes, D. J. Pulford, I. Bennacef, C. A. Parker, P. L. StJean, L. R. Cardon, V. E. Mooser, P. M. Matthews, 
E. A. Rabiner and J. P. Rubio, J. Cereb. Blood Flow Metab., 2012, 32, 1-5.

27 F. Li, J. Liu, Y. Zheng, R. M. Garavito and S. Ferguson-Miller, Science, 2015, 347, 555-558.

28 C. J. Endres, M. G. Pomper, M. James, O. Uzuner, D. A. Hammoud, C. C. Watkins, A. Reynolds, J. Hilton, R. F. Dannals and M. Kassiou, J. Nucl. Med., 2009, 50, 1276-1282.

29 F. Chauveau, H. Boutin, N. Van Camp, F. Dolle and B. Tavitian, Eur. J. Nucl. Med. Mol. Imaging, 2008, 35, 2304-2319.

30 D. R. Owen, O. W. Howell, S. P. Tang, L. A. Wells, I. Bennacef, M. Bergstrom, R. N. Gunn, E. A. Rabiner, M. R. Wilkins, R. Reynolds, P. M. Matthews and C. A. Parker, J. Cereb. Blood Flow Metab., 2010, 30, 1608-1618.

31 A. M. Scarf, K. M. Auman and M. Kassiou, Curr. Mol. Med., 2012, 12, 387-397.

32 R. Narlawar, E. L. Werry, A. M. Scarf, R. Hanani, S. W. Chua, V. A. King, M. L. Barron, R. N. Martins, L. M. Ittner, L. M. Rendina and M. Kassiou, J. Med. Chem., 2015, 58, 8743-8749.

33 A. M. Scarf, C. Luus, E. Da Pozzo, S. Selleri, C. Guarino, C. Martini, L. M. Ittner and M. Kassiou, Curr. Mol. Med., 2012, 12, 488-493.

34 L. Jaremko, M. Jaremko, K. Giller, S. Becker and M. Zweckstetter, Science, 2014, 343, 1363-1366.

35 B. Chelli, A. Salvetti, E. Da Pozzo, M. Rechichi, F. Spinetti, L. Rossi, B. Costa, A. Lena, G. Rainaldi, F. Scatena, R. Vanacore, V. Gremigni and C. Martini, J. Cell. Biochem., 2008, 105, 712-723.

36 W. Kugler, L. Veenman, Y. Shandalov, S. Leschiner, I. Spanier, M. Lakomek and M. Gavish, Cell. Oncol., 2008, 30, 435-450.
37 D. M. Zisterer, N. Hance, G. Campiani, A. Garofalo, V. Nacci and D. C. Williams, Biochem. Pharmacol., 1998, 55, 397-403.

38 S. Castellano, S. Taliani, M. Viviano, C. Milite, E. Da Pozzo, B. Costa, E. Barresi, A. Bruno, S. Cosconati, L. Marinelli, G. Greco, E. Novellino, G. Sbardella, F. Da Settimo and C. Martini, J. Med. Chem., 2014, 57, 2413-2428.

39 B. Costa, E. Da Pozzo, C. Giacomelli, E. Barresi, S. Taliani, F. Da Settimo and C. Martini, Sci. Rep., 2016, 6, 18164.

40 B. Costa, E. Da Pozzo, C. Giacomelli, S. Taliani, S. Bendinelli, E. Barresi, F. Da Settimo and C. Martini, Apoptosis, 2015, 20, 383-398.

41 N. Krupka, P. Strappe, J. Gotz and L. M. Ittner, Plasmid, 2010, 63, 155-160.

42 D. Koller, L. M. Ittner, R. Muff, K. Husmann, J. A. Fischer and W. Born, J. Biol. Chem., 2004, 279, 20387-20391.

43 Y. D. Ke, J. Dramiga, U. Schutz, J. J. Kril, L. M. Ittner, H. Schroder and J. Gotz, PLoS One, 2012, 7, e35678.

44 L. M. Ittner, D. Koller, R. Muff, J. A. Fischer and W. Born, Biochemistry, 2005, 44, 5749-5754.

45 J. Schindelin, I. Arganda-Carreras, E. Frise, V. Kaynig, M. Longair, T. Pietzsch, S. Preibisch, C. Rueden, S. Saalfeld, B. Schmid, J. Y. Tinevez, D. J. White, V. Hartenstein, K. Eliceiri, P. Tomancak and A. Cardona, Nat. Methods, 2012, 9, 676-682.

46 V. Chandrakanthan, A. Yeola, J. C. Kwan, R. A. Oliver, Q. Qiao, Y. C. Kang, P. Zarzour, D. Beck, L. Boelen, A. Unnikrishnan, J. E. Villanueva, A. C. Nunez, K. Knezevic, C. Palu, R. Nasrallah, M. Carnell, A. Macmillan, R. Whan, Y. Yu, P. Hardy, S. T. Grey, A. Gladbach, F. Delerue, L. Ittner, R. Mobbs, C. R. Walkley, L. E. Purton, R. L. Ward, J. W. Wong, L. B. Hesson, W. Walsh and J. E. Pimanda, Proc. Natl. Acad. Sci. U. S. A., 2016, 113, E2306-2315. 